\title{
Central Role of the EGF Receptor in Neurometabolic Aging
}

\author{
Sana Siddiqui, ${ }^{1}$ Meng Fang, ${ }^{1}$ Bin Ni, ${ }^{1}$ Daoyuan Lu, ${ }^{1}$ \\ Bronwen Martin, ${ }^{2}$ and Stuart Maudsley ${ }^{1}$ \\ ${ }^{1}$ Receptor Pharmacology Unit, National Institute on Aging, Baltimore, MD 21224, USA \\ ${ }^{2}$ Metabolism Unit, National Institute on Aging, Baltimore, MD 21224, USA \\ Correspondence should be addressed to Stuart Maudsley, maudsleyst@mail.nih.gov
}

Received 30 March 2012; Accepted 1 May 2012

Academic Editor: Huan Cai

Copyright () 2012 Sana Siddiqui et al. This is an open access article distributed under the Creative Commons Attribution License, which permits unrestricted use, distribution, and reproduction in any medium, provided the original work is properly cited.

\begin{abstract}
A strong connection between neuronal and metabolic health has been revealed in recent years. It appears that both normal and pathophysiological aging, as well as neurodegenerative disorders, are all profoundly influenced by this "neurometabolic" interface, that is, communication between the brain and metabolic organs. An important aspect of this "neurometabolic" axis that needs to be investigated involves an elucidation of molecular factors that knit these two functional signaling domains, neuronal and metabolic, together. This paper attempts to identify and discuss a potential keystone signaling factor in this "neurometabolic" axis, that is, the epidermal growth factor receptor (EGFR). The EGFR has been previously demonstrated to act as a signaling nexus for many ligand signaling modalities and cellular stressors, for example, radiation and oxidative radicals, linked to aging and degeneration. The EGFR is expressed in a wide variety of cells/tissues that pertain to the coordinated regulation of neurometabolic activity. EGFR signaling has been highlighted directly or indirectly in a spectrum of neurometabolic conditions, for example, metabolic syndrome, diabetes, Alzheimer's disease, cancer, and cardiorespiratory function. Understanding the positioning of the EGFR within the neurometabolic domain will enhance our appreciation of the ability of this receptor system to underpin highly complex physiological paradigms such as aging and neurodegeneration.
\end{abstract}

\section{Introduction}

The epidermal growth factor receptor (EGFR) is a 170$\mathrm{kDa}$ single-pass transmembrane (TM) protein. The EGFR belongs to a family of four members: erbB-1/EGFR, erbB2 (HER2/c-neu), erbB3 (Her3), and erbB4 (Her4). The basic EGFR structure contains an immunoglobulin-like extracellular ligand binding domain and an intrinsic tyrosine (Tyr) kinase activity contained within its intracellular carboxyl terminal domain. Extracellular stimulating ligands, for example, epidermal growth factor (EGF), bind to an individual TM receptor and induce a conformational alteration that causes dimerization with another ligand-bound EGFR or with another erbB receptor. The ligand-induced conformational changes then activate the intrinsic tyrosine kinase domains causing subsequent autophosphorylation or transphosphorylation of the opposing receptor in the dimer $[1,2]$. The creation of phosphorylated tyrosines then serves to create a dynamic scaffolding domain for downstream signaling molecules that possess $\mathrm{SH} 2$ or PTB domains, for example, Grb2 or Shc. Not only are positive signaling molecules recruited in this manner but also factors involved in EGFR internalization, such as Eps15 [3], and eventual lysosomal degradation factors, such as c-Cbl $[4,5]$. Many of the signaling functions of the EGFR are mirrored by other members of the receptor tyrosine kinase (RTK) receptor class, for example, ligand-induced tyrosine kinase activation, protein scaffold assembly, and interaction with multiple common downstream factors (phospholipases, phosphoinositide kinases, non-RTKs) [6]. The commonality of function between RTKs indicates that these receptors are highly likely to form important, and strongly interconnected, links between a diverse range of physiological or pathophysiological activities.

1.1. EGFR Activation Profile Diversity. The activation process of the EGFR typically follows the generic process of EGFR ligand stimulation, tyrosine kinase activation, dimerization 
and tyrosine (Tyr) phosphorylation, and then signaling protein complex assembly. However, there are considerable functional nuances within this process that serve to profoundly condition and add "texture" to the signaling output from these important receptors. For example, the specific nature of the carboxyl terminal domain phosphorylation events provides a mechanism by which a greater variety of signaling information can be conveyed to the intracellular milieu. Tyr phosphorylation for EGFR may occur at various sites including Tyr 845, 992, 1045, 1068, 1148, 1173, or 1086. Phosphorylated Tyr residues act as binding sites for proteins containing Src-homology 2 domains (SH2) such as Grb2, Shc and phospholipase C-gamma (PLC- $\gamma$ ) . Phosphorylation at Tyr 845 in the kinase domain is involved in stabilizing the activation loop, maintaining the active state enzyme, and providing a binding surface for substrate proteins $[7,8]$. The non-RTK c-Src is also involved in EGFR phosphorylation at Tyr 845 [9]. The SH2 domain of PLC$\gamma$ binds at phospho-Tyr 992, which results in activation of PLC- $\gamma$-mediated downstream signaling [10]. A pair of phosphorylated EGFR residues (Tyr 1148 and Tyr 1173) provides a docking site for the Shc scaffold protein, and both sites are involved in mitogen activated protein kinase (MAPK) signaling activation [1]. Phosphorylation of EGFR at Tyr 1045 creates a major docking site for the adapter protein c-Cbl, leading to receptor ubiquitination and degradation following EGFR activation $[4,5]$. The multifunctional Grb2 adapter protein binds the EGFR at phospho-Tyr1068 once the EGFR is activated [11]. Phosphorylation of the EGFR at specific serine (Ser) and threonine residues inhibits EGFR kinase activity. EGFR carboxy-terminal residues Ser1046 and Ser1047 are phosphorylated by CaM kinase II; mutation of either of these serines results in upregulated EGFR tyrosine autophosphorylation [12]. Therefore the pattern and timing of such EGFR posttranslational phosphorylation events strongly affect its cellular disposition and eventual signaling capacity. Such a wide flexibility of function is typically characteristic of protein factors that are likely to form multidimensional interactions within more complex physiological paradigms $[13,14]$.

1.2. Diversity of EGFR-Stimulatory Factors. The EGFR possesses a highly complex relationship with its stimulating ligands/factors. Endogenous peptide-based ligands that can activate the EGFR include epidermal growth factor (EGF), transforming growth factor (TGF)- $\alpha$, amphiregulin (AR), heparin-binding EGF (HB-EGF), betacellulin, epiregulin (ER), and epigen [15]. The EGFR is almost unique amongst receptor systems in that it serves as a molecular integration site for multiple types of stimuli including: peptide ligands, metal ions, ultraviolet and gamma radiation, osmotic shock, membrane depolarization, and oxidative radicals [16]. This wide range of stimuli again reinforces the concept that the EGFR acts as a functional keystone in "higher-order" complex systems that may underpin multifactorial global somatic actions such as aging and metabolism.

The EGFR can be activated by small transition metal ions such as zinc and copper $(\mathrm{Cu})$ [17]. In addition to simple metal ions, ultraviolet (UV) radiation activates the EGFR by two ligand-binding independent mechanisms: Tyr phosphorylation of the receptor [18-20], and via oxidative inhibition of the RPTP- $\kappa$ [21]. It appears that the generation of reactive oxygen species (ROS) may in some cases be secondary to EGFR activation. These ROS may lead to the reversible inactivation of a crucial protein for EGFR activation, that is, protein tyrosine phosphatases (PTPs) by oxidizing the catalytic cysteine in their active site $[22,23]$.

Heptahelical G-protein-coupled receptors (GPCRs), which classically were not primarily associated with tyrosine kinase signaling cascades, have subsequently been demonstrated to exert a profound regulatory capacity over RTK systems, including the EGFR [24-29]. This GPCR-RTK regulatory capacity has been demonstrated for multiple types of GPCRs, for example, muscarinic, bombesin, thrombin, endothelin, lysophosphatidic acid (LPA) receptors, which perhaps suggests that this is a common function for GPCRs in most physiological processes. There appear to be multiple mechanisms that can mediate this functional GPCR-RTK interaction, however one of the most studied involves the GPCR-induced processing of pro-HB-EGF to its soluble form through the activation of intramembrane metalloproteinases [30]. Matrix metalloproteinases (MMPs) shed the pro-form of the EGFR ligands which are then locally liberated and able to induce classical EGFR activation. It is interesting to note that this so-called G protein-coupled receptor RTK "transactivation" is a process not only limited to heptahelical GPCRs. For example, the insulin-like growth factor-1 receptor (IGF-1R), classically considered to possess an RTK structure, is actually a "functional G protein-coupled receptor" as it is able to stimulate guanine nucleotide exchange event within its associated $G$ proteins [31]. IGF1-mediated stimulation of the IGF-1R can therefore result in a "transactivation" of the EGFR in a manner similar to that induced by heptahelical GPCR activity [32]. This interaction between the IGF-1R and the EGFR perhaps forms one of the first points of molecular integration between neurological and metabolic activities. In addition to this functional system bridge between neuronal and metabolic systems, ligands of G $\alpha \mathrm{q} / 11$-coupled GPCRs that are associated with insulin resistance, such as serotonin, endothelin-1, and thrombin, may also stimulate HB-EGF production and transactivate EGFR in 3T3-L1 adipocytes. Serotonin has been shown to additionally have this effect in primary adipocytes and myotubes [33]. Not only can serotonin induce activation of the EGFR but it also appears to be able to regulate the posttranslational activity, via serine phosphorylation and the mTOR pathway, of the insulin/IGF-1 receptor-associated protein, IRS-1 [33]. IRS1 and -2 are insulin receptor-associated scaffold proteins essential for effective glucose metabolism in multiple energyregulatory tissues such as the liver [34]. This serotoninergic synergy between IRS-1 phosphorylation and HB-EGFmediated EGFR stimulation has been demonstrated to play a key role in serotonin-induced insulin resistance [35]. This molecular linkage may underpin the ability of antiserotoninergic therapy amelioration of glucose tolerance in diabetics [36]. Insulin resistance has been shown to 
have causal relationships with proinflammatory cytokines (including adipokines) [37], prolonged/amplified insulin stimulation, oxidative stress, and endoplasmic reticulum stress [38-40]. Indicating the significant interaction of the EGFR system with other signaling modalities, it has been shown that activation of the growth hormone cytokine receptor can induce phosphorylation of EGFR in preadipocytic fibroblast cell lines. This cytokine receptormediated transactivation event effectively modulates EGF-induced EGFR trafficking and signaling [41]. It is important to note that the growth hormone ligand and receptor system is one of the most important factors that controls both IGF-1 expression and secretion as well as somatic energy metabolism.

It has been revealed in recent years that the Toll-like receptor (TLR) system is important for neurological health [42]. Ligand activation of multiple TLR isoforms has been demonstrated to induce subsequent activation of EGFRs [43, 44]. This pathway involves the activation of nicotinamide adenine dinucleotide phosphate and the generation of reactive oxidative species (ROS). Subsequent activation of tumor necrosis factor (TNF)- $\alpha$-converting enzyme (TACE) leads to the liberation of TGF- $\alpha$ from the epithelium and productive ligation of the EGFR [45]. TLR2 activation by lipoteichoic acid leads to a disintegrin and metalloproteinase (ADAM)-10-induced cleavage of HB-EGF, another EGFR ligand. Amphiregulin has also been shown to be released in response to TNF- $\alpha[46]$.

It is clear therefore that in addition to its widespread expression and highly textured signaling activity, the EGFR is subject to multiple and highly diverse signaling inputs both from other receptor systems and small molecules and ions. These combined molecular factors and emerging evidence of functional overlap of EGFR activities from neuronal to metabolic systems suggest that the EGFR system may exert a "near omnipotent" function in aging biology.

\section{EGFR and the Control of Neurometabolic Physiology}

The EGFR, and its axis of ligands demonstrate a widespread expression profile across the central nervous system (CNS) [47]. Substantial EGFR expression is found in the neocortex and limbic cortex, cerebellum, cerebrovascular endothelial cells $[48,49]$, and the midbrain [50]. EGFR has been detected in the hippocampal pyramidal cells, Purkinje cells, large multipolar neurons of the dentate nucleus, anterior horn cells, dorsal root ganglion cells, cells of the dorsal nucleus of Clark, intermediolateral column cells, and ependymal cells [51]. In the human fetal brain, EGFR has been shown to be expressed in the subventricular zone (SVZ) [52], hippocampus, and cerebellum [53]. This expression pattern in the two primary areas of adult neurogenesis suggests that the EGFR could also play a strong role in age-related neuronal survival and regeneration. The EGFR has also been implicated in chemotactic migration in the developing telencephalon with implication of HB-EGF involvement [54]. EGF appears to act as a mitogen for neural stem and progenitor cells (NS/NPCs) in the CNS as well as numerous other cell types involved in neurometabolic activity. Along with EGF, HB-EGF and TGF- $\alpha$ also promote proliferation in the SVZ of an adult mouse HB-EGF [55]. In vitro, EGF maintains NS/NPCs in the proliferative state, whereas in the normal rodent brain, it induces proliferation and migration in the SVZ. EGF can also increase neuronal replacement in the ischemia-injured adult striatum. In addition, Sun et al. (2010) found that EGF is neuroprotective rather than neurogenic when protecting the brain from injury [56].

Notch proteins are a family of transmembrane receptor proteins with repeated extracellular EGF and titular Notch domains. Notch interacts with cell-bound ligands (Delta-like, Jagged) that facilitate an inter-cellular signaling pathway that is critical in cellular and tissue development. Notch family members regulate developmental processes by controlling cell fate decisions [57]. Notch and EGFR have fundamental and selective roles in the maintenance of NS/NPCs in the SVZ. Notch signaling promotes proliferative signaling during neurogenesis and its activity is inhibited by Numb to promote neural differentiation. The Numb gene product controls binary cell fate decisions in peripheral and central nervous systems during neurogenesis. Notch and EGFR pathway interaction regulates neural stem cell number and selfrenewal [58]. Altering particular signaling mechanisms in selective cell types of the SVZ can cause profound changes in the overall cell composition of this neurogenic region of the adult brain. Defining interactions and homeostatic mechanisms that occur between different types of SVZ cells under normal conditions provides crucial information on possible alterations of specific signaling pathways that might occur under pathological conditions or after brain injury.

The aspartyl protease, $\gamma$-secretase, is a multisubunit protease which mediates the coordinated intramembrane proteolysis of both Notch and amyloid-precursor protein (APP), which are both implicated in the etiology of Alzheimer's disease (AD). In some cell types the expression of EGFR and $\gamma$-secretase have been reported to be inversely related to each other, suggesting the existence of strong functional connection between these two systems [59]. In a study of squamous cell carcinoma, Notch and EGFR were shown to participate in the tumor suppressor function of $\gamma$-secretase, again reinforcing the existence of a physiologically-relevant EGFR- $\boldsymbol{y}$-secretase interaction [60].

Given the considerable evidence for a strong role of the EGFR in neural stem cell development it is unsurprising that one of the functional sequelae of this activity is the maintenance of memory pattern formation in the hippocampus. Two of the most important regions of the CNS for adult stem cell-mediated neurogenesis are the hippocampal CA1 and dentate gyrus (DG) [61]. Membrane-tethered proligand, HB-EGF, is found in cells within many regions of the CNS, for example, cerebellum, cerebral cortex as well as the hippocampus [62]. The specific hippocampal expression of HB-EGF and the association of the EGFR with neurodevelopmental processes have led to the implication of EGFR signaling in synaptic plasticity and memory formation [55]. HB-EGF knockout mice demonstrate also reduced CNS 
expression levels of neurotrophic factors including brainderived neurotrophic factor (BDNF), which is a ligand for the tropomyosin-receptor kinase- (Trk-) B receptor [55]. Expression levels of BDNF and $\operatorname{TrkB}$ receptor activity are both strongly correlated to the regulation of synaptic architecture and the ability to form and retain memory patterns. The hippocampal regions, CA1/DG, demonstrate a tremendously high requirement for energetic support due to their constant stimulation both from sensory inputs and higher areas of the brain. Their huge energetic load therefore makes CA1/DG neurons extremely sensitive to the metabolic status of the individual [63-65].

One of the strongest points of physiological neurometabolic intersection may occur via the neurometabolic control of reproductive activity. It has been demonstrated that there are strong gender-specific molecular mechanisms that link hippocampal cognitive function to centrallycontrolled reproductive behavior [66-69]. It has also been demonstrated that the EGFR is localized to the anterior pituitary [70] along with EGF [71] and TGF- $\alpha$ [72], implicating them in the reproductive hypothalamic-pituitary axis [73]. In the anterior pituitary, EGFR has been identified in lactosomatotrophs [74], corticotrophs [75], and gonadotrophs $[76,77]$. The EGFR has been directly implicated in corticotroph proliferation and hormone secretion, while TGF- $\alpha$ has been implicated in EGFR-dependent estrogen-mediated corticotroph cell proliferation $[78,79]$. In addition to these reproductive functions, EGFR activity is also closely associated with the dynamic regulation of prolactin transcription and synthesis [80].

\section{Role of the EGFR in Neurometabolic Pathophysiology}

As one would expect from its multifactorial biological activity, the genomic inactivation of EGFR by homologous recombination results in profound systemic effects. EGFR genomic inactivation can induce three different phenotypes that range from peri-implantation lethality to postnatal lethality [81]. EGFR-inactivated mice die at different stages of development depending on their genetic background; EGFR mutant mice may die at gestation (129/Sv), at birth $(\mathrm{C} 57 \mathrm{Bl} / 6)$, or they may live up to 8 or 20 days (CD1, MF1, 129Sv/J Swiss Black or C3H) [82-86]. After parturition, the surviving animals may suffer from impaired epithelial development in organs such as the skin, lung and gastrointestinal tract [83] as well as the placenta. Furthermore, there is a strain-independent postnatal neurodegeneration in the frontal cortex, olfactory bulb, and thalamus in surviving EGFR-null mice [82]. This neurodegeneration is characterized by massive apoptosis and upregulation of c-fos [82]. The mildest form of EGFR inactivation leads to epithelial immaturity and postnatal death due to respiratory failure and necrotizing enterocolitis-like lesions in the intestine [81]. The defects seen in this "postnatal lethality phenotype" manifest in the classical EGF-responsive organs (skin, intestine) and organs undergoing branching morphogenesis during development (lung, kidney, mammary gland, pancreas, and prostate) and, thus, are in concordance with the concept of EGF family members being important epithelial mitogens. Intestinal changes observed in the EGFR-inactivated mice differ in the level of severity, the endpoint being severe mucosal lesions and necroses (cell death) [81].

Within the CNS, it has been suggested that the EGFR is likely to mediate the effects of EGF/TGF- $\alpha$ on neuronal differentiation [87], survival [88-90], as well as glial proliferation $[91,92]$. While many neurons of the CNS constitutively express the EGFR $[48,49]$, glia and endothelial cells demonstrate induced receptor expression following acute injury or chronic neurodegeneration [48, 49, 9395]. Glial cells are vital for the generation of a dynamic support structure for CNS activity in the face of altered energy availability or oxidative stress [96]. TGF- $\alpha$-gene expression in glial cells is a component of the hypothalamic response to injury [97] and it has been reported that during development, the increased bias towards glial differentiation is not dependent on EGFR signaling [98]. EGFR expression appears to the crucial for the proliferation and differentiation of astrocytes [92], however, it is only one of a number of means by which astrocytes can be induced. Burrows et al. (1997) demonstrated that misexpression of EGFRs promoted astrocyte development prematurely in vivo [99]. Furthermore, it was suggested that EGFRs may induce the development of astrocytes by regulating the responses of progenitors to various extrinsic signals such as leukemia inhibitory factor (LIF) and bone morphogenetic proteins (BMPs) [99]. It was also later demonstrated that EGFRs elevate STAT3 expression and increase its phosphorylation by LIF and that EGFRs further regulate LIF downstream of STAT3 but they do not regulate changes in responsiveness to BMPs [100].

Mice that do not possess EGFR develop neurodegeneration involving the frontal cortex and olfactory bulbs. It has been shown that EGFR signaling controls cortical degeneration by the regulation of cortical astrocyte apoptosis [101]. Midbrain astrocytes where EGFR is absent are not affected; however, some mutant cortical astrocytes possess an increased incidence of apoptosis which is mediated by an Akt-caspase-dependent mechanism and these cells demonstrate a reduced ability to support neuronal survival [101]. These results suggest two functionally distinct astrocyte populations exist, which are differentially dependent on EGFR signaling for their survival and also for their ability to support neuronal survival [101]. These spatial differences in astrocyte composition provide a mechanism for the regionspecific neurodegeneration in EGFR null mice [101].

TGF- $\alpha$ contributes to the neuroendocrine regulation of female puberty by stimulating the release of luteinizing hormone-releasing hormone (LHRH) [97]. It has been proposed that TGF- $\alpha$ may be involved in a glial-neuronal interaction where it first stimulates PGE2 from glial cells which in turn elicits LHRH from neuronal terminals [102]. Interestingly astrocytes, but not LHRH neurons, express EGFR [103]. Disruption of astroglial EGFR signaling leads to irregular estrous cycles and a decreased secretion of LH in female mice which eventually can cause infertility [104]. The EGFR and TGF- $\alpha$ are present in the suprachiasmatic nucleus 
(SCN), which is the core circadian pacemaker. The SCN releases factors acting locally within the hypothalamus, more specifically in the neurons of the subparaventricular zone. It has also been reported that EGFR has a circadian-timedependent neuromodulatory function in the SCN $[105,106]$. TGF- $\alpha$ has been implicated as an inhibitor of locomotion and sleep-wake cycles [107]. In hamsters, these data are confirmed, and, furthermore, it was shown that central administration of TGF- $\alpha$ induced weight loss [108].

\section{EGFR and Neurodegenerative Disease}

$\mathrm{AD}$ is one of the most prevalent familial and sporadic neurodegenerative disorders. One of the strongest risk factors for $\mathrm{AD}$ appears to be advancing age. In addition to the clear neurological basis of $\mathrm{AD}$, the contribution of metabolic factors to this disorder as well as other neurological processes has been the subject of considerable recent scrutiny [65, 109111]. In $\mathrm{AD}$ pathology, aggregates and deposits of the protein fragment $\beta$-amyloid (plaques) and twisted strands of the protein Tau (neurofibrillary tangles) induce the generation of nerve cell damage and cell death in areas of the brain including the cortex and especially the hippocampus [110, $112-114]$. With respect to an association with $\mathrm{AD}$ etiology it has been demonstrated that EGFR expression in the rat brain reduces with age both in males and females [115]. ADrelated neuritic plaques observed in the cerebral cortex and hippocampus of patients with $\mathrm{AD}$ also immunostain positively for EGFR [93]. In addition, it has been demonstrated that EGFR expression is upregulated in astrocytic cells in $\mathrm{AD}$ [116] and that EGFR-null astrocytes from mutant cortices in mice have an impaired proliferative capacity both in vitro and in vivo $[82,86]$. With respect to the potential involvement of the EGFR in the etiology neurometabolic pathophysiologies, such as $\mathrm{AD}$, a strong role for metal ion activity is likely. It has been demonstrated that $\mathrm{AD}$ is often associated with a central nervous imbalance of transition metal levels which may lead to neurotoxicity. Transition metals facilitate oxygen transport and its eventual usage by nervous tissue. The same metal ion chemistry if dysregulated, for example, $\mathrm{Cu}$ imbalance, can induce the generation of reactive oxygen species (ROS) which are strongly associated with $\mathrm{AD}$ and pathological aging [117]. Interestingly, clioquinol-Cu metal complexes, which are cell-permeable, can be employed to ameliorate $\mathrm{AD}$ pathology via their ability to stimulate the EGFR in neuronalderived cell lines causing a reduction in $\beta$-amyloid levels [118]. This metal ion process also appears to involve the activation of TM matrix metalloproteinases (MMPs) as well the nonreceptor tyrosine kinase c-Src [118]. Iron is another metal implicated in $\mathrm{AD}$ through its capacity to modulate the ability of amyloid peptides to yield ROS [119] which then may serve to exacerbate the disorder further [120].

EGFR immunoreactivity has been localized to the brain, pituitary, skin vascular endothelial cells of clinically diagnosed, pathologically confirmed AD patients when samples were collected postmortem [95]. It has also been reported that EGFR is localized to the lumenal surface of endothelial cells and that EGFR immunoreactivity in brain vasculature was present in all assessed elderly patients with dementia, when compared to nondemented patients [94]. As microvascular damage and hypertension are strongly associated with intermittent ischemia, hypoxia, and $\mathrm{AD}$-related pathology, it seems likely that the cerebrovascular activity of the EGFR is an important aspect of its role in neurodegenerative pathophysiology. In addition to a potential role in $\mathrm{AD}$, it has been shown that there is an increased expression of EGFRs in the striatum in chronic Parkinsonian syndromes but not in acute models of the disease [121]. Depletion of neuronal dopamine is observed in Parkinson's disease and this subsequently would lead to decreased precursor cell proliferation in the SVZ as well as a reduction in local EGF production. EGFR positive cells have been reported to be depleted in SVZ in Parkinson's disease as well: these data collectively indicate a role of dopamine-EGFR signaling loop in regulation of neurogenesis of dopaminergic neurons [122]. This process appears to involve an Wnt5adopamine D2 receptor interaction in association with the EGFR [123]. Taken together there appear to be multiple and mechanistically diverse routes by which the EGFR may be involved in the neuronal aspect of aging-related disorders and neurodegeneration.

\section{EGFR Regulates Aging-Related Metabolic Activity}

Aging is considered to be one of the most complex physiological processes known. Despite its enormous molecular complexity there appear to be several molecular mechanisms in which the aging process can considered in a generic sense, for example, disruption of hormonal axes, accumulated oxidative stress, increasing nucleic acid instability, and a reduction of metabolic efficiency. Even among these common aging factors, metabolism for one appears to be vital for all of the physiological aspects of aging. It is not surprising therefore that many of the effective antiaging strategies intersect with this important factor $[109,124-$ 130]. Therefore, if metabolic function is an overarching factor in the aging process, the question arises as to how the multifunctional EGFR might affect this profoundly important process.

Historically, however, the EGFR has been more commonly associated with cancer biology as opposed to neuronal function, metabolism, or aging. Given that the EGFR is one of the most widely expressed growth factor receptors, it is implicated in playing an important role in the proliferation of a wide variety of cell types in addition to the previously studied cancerous cells [131]. For example, the EGFR is amplified and overexpressed in tumors of epithelial [131] and glial origins [132] as well as other numerous neurometabolic-related tumors observed in humans. Viruses often associated with cancers, such as the hepatitis B virus, which is associated with hepatocellular carcinoma, lead to upregulation of EGFR signaling [133, 134]. Recent research however has started to reveal a more widespread contribution of the EGFR to complex physiological processes such as energy metabolism. In gastric cell lines, transactivation 
of the EGFR intimately involves leptin-signaling. Leptin is a cytokine hormone secreted by adipocytes that regulates body weight by decreasing food intake and energy expenditure [135]. EGFR is also constitutively expressed in epithelium and airway smooth muscle (ASM) [136] as well as in hepatocytes [137]. The liver represents one of the most important organs with respect to the global somatic control of both energy expenditure and nutrient storage. Interestingly, it has been reported that the EGFR demonstrate a 2-fold higher expression in adult rat males compared to females and this phenomenon may be influenced by secretory rhythm of growth hormone $(\mathrm{GH})$ in the pituitary [138].

Perinatal deletion of EGFR in hepatocytes results in decreased body weight, whereas deletion in the adult liver does not appear to affect body mass. Although liver function was not affected, after partial hepatectomy, mice lacking hepatic EGFR exhibit increased mortality and elevated serum transaminases, indicative of liver damage. EGFR has also been shown to be a critical regulator of hepatocyte proliferation in the initial phases of liver regeneration [139]. Several studies have investigated various regulatory factors that contribute to the affinity of EGF to EGFR in rat hepatocytes, for example, thyroid hormones [140], age [141], sex [141], fasting state [142], liver regeneration [143], and an imposed experimental diabetic state [144-146]. In accordance with this, a decreased hepatic EGFR expression has been reported in diabetic mice [147, 148]. Given the aforementioned molecular connectivity between the EGFR and the insulin/IGF-1/GH signaling systems it is logical that insulin may be one of the most important factors that regulate EGFR gene expression in the liver [147]. EGF and EGFR have been shown to be involved in an antiapoptotic effect in mouse hepatocytes [149] while EGF decreases the glucose transporter 2 expression level in chicken hepatocytes via PKC-MAPK [150]. Insulin deficiency causes a decrease in EGFR and its mRNA gene expression: therapeutic introduction of exogenous insulin restored the EGFR expression to control levels [147]. In addition to the insulinotropic regulation of hepatic EGFR function, the EGFR can be tyrosine-phosphorylated in the liver in a time- and dosedependent manner in response to $\mathrm{GH}$ [151].

Carcinoembryonic antigen-related cell adhesion molecule 1 (CEACAM1) is a cell adhesion protein and recently identified a substrate of the EGFR [152]. Once phosphorylated by EGFR activation, CEACAM1 appears to mediate increases in insulin sensitivity and can decrease insulindependent mitogenesis in vivo. An attenuated response to insulin stimulation is causally related to obesity, type 2 diabetes, and metabolic syndrome, and improved wholebody insulin sensitivity is important in the treatment of these metabolic disorders [153]. CEACAM1 therefore appears to play a central role in connecting EGFR activity with the control of central obesity/insulin resistance. The connection between EGFR activity and obesity is further reinforced by the observation that obesity is strongly associated with an increased mortality rate in cancer patients $[154,155]$. The mechanism(s) linking altered metabolic pathways to mitogenic activity may involve EGFR activation by fatty acids independently of the cognate growth factor ligands of
EGFR $[156,157]$. Free fatty acids (FFAs) are upregulated in fasting plasma of obese individuals [158]. Rather than being considered a passive organ adipose tissue is now appreciated as a dynamic endocrine regulatory organ. In addition to releasing FFAs [159] HB-EGF can be released from adipose tissue in obese individuals into the portal circulation [160]. Both FFAs and HB-EGF possess the capacity to engender EGFR activation in epithelial cells [152].

As we have discussed, in addition to its strong role in hepatic function, the EGFR also appears to coordinate multiple aspects of the glucose metabolic system. EGFR and the EGFR ligands, especially TGF- $\alpha$, is functionally expressed in the developing pancreas [161]. EGFR expression is essential for normal pancreatic development and important in postnatal $\beta$ cell growth [162]. Furthermore, EGFR signaling is essential for pancreatic islet $\beta$ cell mass expansion during a high-fat diet and pregnancy. In these scenarios cellular replication appears to be the primary mechanism for the compensatory $\beta$ cell mass expansion [163]. EGFR signaling however was not crucial to increase $\beta$ cell proliferation after pancreatic duct ligation, which serves as a model for islet neogenesis. In EGFR-deficient mice, the development of $\beta$ cells occurs at a later stage and the nascent $\beta$ cells have a definite migratory defect [162]. EGFR ligands, EGF, HB-EGF, and betacellulin have all been implicated in $\beta$ cell replication, differentiation and lineage determination of developing islet cells [164167]. In addition to direct ligand-induced activation of the pancreatic EGFR, local GPCR-mediated transactivation of the receptor also appears to be potentially important in the EGFR-mediated regulation of glucose metabolism [168]. Glucagon-like peptide 1 (GLP-1) is secreted by intestinal L-cells in response to fat meals and carbohydrates [169171]. In addition to its direct roles in the alimentary canal, for example, regulation of gastric emptying, GLP-1 also can functionally regulate $\beta$ cell function in the pancreas, thereby providing another mechanism to control energy metabolism. The GLP-1 peptide activates its cognate Class B-type GLP-1 receptor to induce a c-Src-dependent EGFR transactivation process. This signaling system involves a proteolytic processing of membrane-anchored betacellulin, or other EGF-like ligands, that results in a strong PI3kinase activation resulting in an effective increase in $\beta$-cell proliferation [172].

A common pathological aspect of metabolic aging is a slow inevitable generation of global insulin resistance [13]. Insulin resistance and the associated metabolic syndrome lead to a reduction in the ability of multiple cell types, and especially neurons, to uptake glucose, regulate calcium homeostasis and respond positively to trophic and neurotrophic stimuli [173]. In addition to generating a global disruption of neuronal energy balance, protracted insulin resistance leads to a loss of vascular smooth muscle cell (VSMC) functional regulation and promotion of VSMC migration [174]. The latter is crucial in atherosclerotic development and wound healing. Insulin has also been implicated in epidermal wound healing though EGFR signaling [174]. Insulin can induce transactivation of EGFR by ADAMmediated HB-EGF-dependent process in VSMCs [174]. In quiescent fibroblasts, the mitogenic effect of EGF requires 
activation of the IGF-1R by circulating ligands including IGF-I, IGF-II, or insulin [175]. As alterations in VSMC tone and function are likely to affect systemic hypertension, it is interesting to note that elevated plasma glucose can also result in the transactivation of the EGFR in renal disorders [176].

\section{EGFR and TrkB Signaling: Potential Mediators of the Neurometabolic Interface}

Considerable scientific progress has been made in studying EGFR since Cohen and Carpenter's publication (1975) that EGF induces precocious eyelid opening in neonatal mice [177]. The EGFR demonstrates an unprecedented number of functional interactions with other receptors, ligands, and molecules other than its own cognate ligands. Understanding these interactions is crucial to understanding the many different levels at which it is contributing to neurometabolic processes. However, the placing of the EGFR in such a central and important role in aging is overly simplistic. There are of course likely to be other factors that also possess a multidimensional impact upon neurometabolic function. For example, the interaction of the EGFR with the metal ion complexes leads to the resultant generation of downstream signaling phenotypes which are more characteristic of that engendered by the activation of the neurotrophic $\operatorname{TrkB}$ signaling system. The activity of the neurotrophic receptor family is already appreciated to be incredibly important to the presence and generation of $\mathrm{AD}$ pathology [178]. Trk receptors are necessary for the survival, differentiation and maturation of the developing brain [179]. Multiple lines of evidence have demonstrated a reduction of brainderived neurotrophic factor (BDNF), the cognate ligand for the TrkB receptor, in the brain of $\mathrm{AD}$ patients [180-183]. Furthermore, TrkB has been reported to be important for LTP, a process considered to underpin memory function, in hippocampal CA1 neurons $[184,185]$. Both the TrkB and EGFR signaling systems could potentially form a functional link that generates a combined regulatory system deeply associated with the majority of signaling systems controlling the aging process. It is interesting to note that both the TrkB and EGFR receptor systems can be directly linked through GPCR "transactivation" signaling mechanisms. Therefore it is likely that a "higher-order" synergy between TrkB and the EGFR could account for a significant component of the neurometabolic aging phenotype. Also through their common GPCR interaction in this "super-system" could be easily targeted in a therapeutic manner as currently over half of the effective pharmacopeia is designed to employ GPCR signaling systems. Such potential agents targeting this EGFR-TrkB network may be able to exert tremendously powerful therapeutic effects in aging and neurodegenerative paradigms.

\section{Conclusion}

In this paper we have attempted to uncover the context of neuronal and metabolic interaction at the molecular level during the aging process. Enormously complex systems such as aging entail functional interaction of a myriad of physiological and molecular signaling systems. To provide a workable molecular framework on which to regulate and control such an enormous system it is likely that the existence of factors that can bridge, and adapt to, a multiplicity of signals, receptors, cell types, and tissues is crucial to the orchestration of the overall network. It is at this level that individual functional entities, such as the EGFR receptor system, may come to prominence. In its ability to interact and regulate multiple neuronal and metabolic functions across lifespan, the EGFR may indeed be one of the most important molecules whose enhanced study could yield future insights of tremendous importance for gerontology. In our paper we have drawn together evidence to aid the appreciation of the truly multidimensional role of EGFR at the systemic level in neurometabolic processes and in the neurodegenerative trajectories seen in the aging process.

\section{Abbreviations}

\begin{tabular}{|c|c|}
\hline AD: & Alzheimer's disease \\
\hline ADAM: & A disintegrin and metalloproteinase \\
\hline Akt: & Ak-thymoma8 \\
\hline APP: & Amyloid- $\beta$ precursor protein \\
\hline AR: & Amphiregulin \\
\hline ASM: & Airway smooth muscle \\
\hline BDNF: & Brain-derived neurotrophic factor \\
\hline BMPs: & Bone morphogenetic proteins \\
\hline CA1: & Cornu Ammonis 1 \\
\hline CaM kinase II: & $\begin{array}{l}\mathrm{Ca}^{2+} / \text { calmodulin-dependent protein } \\
\text { kinase }\end{array}$ \\
\hline c-Cbl: & $\begin{array}{l}\text { Casitas B-lineage lymphoma } \\
\text { protooncogene }\end{array}$ \\
\hline c-fos: & Fbj osteosarcoma oncogene \\
\hline c-Src: & Rous sarcoma oncogene \\
\hline CNS: & Central nervous system \\
\hline CQ: & Clioquinol \\
\hline $\mathrm{Cu}:$ & Copper \\
\hline DG: & Dentate gyrus \\
\hline EGF: & Epidermal growth factor \\
\hline EGFR: & Epidermal growth factor receptor \\
\hline Eps15: & $\begin{array}{l}\text { Epidermal growth factor receptor } \\
\text { phosphorylation substrate-15 }\end{array}$ \\
\hline ER: & Epiregulin \\
\hline ERK: & Extracellular-signal-regulated kinases \\
\hline FFAs: & Free fatty acids \\
\hline GH: & Growth hormone \\
\hline GLP-1: & Glucagon-like peptide 1 \\
\hline GLP-1R: & Glucagon-like peptide 1 receptor \\
\hline GPCR: & G-protein coupled receptor \\
\hline Grb2: & Growth factor receptor-binding protein 2 \\
\hline HB-EGF: & Heparin-binding epidermal growth factor \\
\hline IGF-1: & Insulin growth factor-1 \\
\hline IGF-1R: & Insulin growth factor- 1 receptor \\
\hline IRS-1: & Insulin receptor substrate- 1 \\
\hline LHRH: & luteinizing hormone-releasing hormone \\
\hline LIF: & Leukemia inhibitory factor \\
\hline LPA: & Lysophosphatidic acid \\
\hline LTP: & Long-term potentiation \\
\hline
\end{tabular}


MAPK: Mitogen-activated protein kinase

MMPs: Matrix metalloproteinases

NS/NPCs: Neural stem and progenitor cells

PBMCs: Peripheral blood mononuclear cells

PGE2: $\quad$ Prostaglandin E2

PI3K: $\quad$ Phosphoinositide 3 kinase

PKC: $\quad$ Protein kinase $\mathrm{C}$

PLC- $\gamma$ : Phospholipase C gamma

PTB: $\quad$ Protein tyrosine binding domain

p-Tyr: Phosphorylated tyrosine

Ras: Rat sarcoma viral oncogene

RPTP- $\kappa$ : Receptor protein tyrosine phosphatase kappa

ROS: $\quad$ Reactive oxygen species

RTK: $\quad$ Receptor tyrosine kinases

Ser: $\quad$ Serine

SH2: $\quad$ Src homology 2 domain

Shc: $\quad$ Src homology construct

Src: $\quad$ Rous sarcoma protein

STAT3: $\quad$ Signal transducer and activator of transcription 3

SVZ: Subventricular zone

TACE: Tumor necrosis factor alpha-converting enzyme

TGF- $\alpha$ : $\quad$ Transforming growth factor alpha

TLR: Toll-like receptors

TM: Transmembrane

TNF- $\alpha$ : Tumor necrosis factor alpha

Trk: $\quad$ Tropomyosin receptor kinase

Tyr: $\quad$ Tyrosine

UV: $\quad$ Ultraviolet

VSMC: Vascular smooth muscle cell.

\section{Acknowledgment}

This work was supported by the Intramural Research Program of the National Institute on Aging, National Institutes of Health.

\section{References}

[1] E. Zwick, P. O. Hackel, N. Prenzel, and A. Ullrich, "The EGF receptor as central transducer of heterologous signalling systems," Trends in Pharmacological Sciences, vol. 20, no. 10, pp. 408-412, 1999.

[2] P. O. Hackel, E. Zwick, N. Prenzel, and A. Ullrich, "Epidermal growth factor receptors: critical mediators of multiple receptor pathways," Current Opinion in Cell Biology, vol. 11, no. 2, pp. 184-189, 1999.

[3] T. Sorkina, A. Bild, F. Tebar, and A. Sorkin, "Clathrin, adaptors and eps 15 in endosomes containing activated epidermal growth factor receptors," Journal of Cell Science, vol. 112, no. 3, pp. 317-327, 1999.

[4] G. Levkowitz, H. Waterman, S. A. Ettenberg et al., "Ubiquitin ligase activity and tyrosine phosphorylation underlie suppression of growth factor signaling by c-Cbl/Sli-1," Molecular Cell, vol. 4, no. 6, pp. 1029-1040, 1999.

[5] S. A. Ettenberg, Y. R. Rubinstein, P. Banerjee, M. M. Nau, M. M. Keane, and S. Lipkowitz, "cbl-b inhibits EGFreceptor-induced apoptosis by enhancing ubiquitination and degradation of activated receptors," Molecular Cell Biology Research Communications, vol. 2, no. 2, pp. 111-118, 1999.

[6] B. Martin, R. Brenneman, E. Golden et al., "Growth factor signals in neural cells: coherent patterns of interaction control multiple levels of molecular and phenotypic responses," Journal of Biological Chemistry, vol. 284, no. 4, pp. 24932511, 2009.

[7] J. A. Cooper and B. Howell, "The when and how of Src regulation," Cell, vol. 73, no. 6, pp. 1051-1054, 1993.

[8] S. R. Hubbard, L. Wei, L. Ellis, and W. A. Hendrickson, "Crystal structure of the tyrosine kinase domain of the human insulin receptor," Nature, vol. 372, no. 6508, pp. 746-754, 1994.

[9] J. S. Biscardi, M. C. Maa, D. A. Tice, M. E. Cox, T. H. Leu, and S. J. Parsons, "C-Src-mediated phosphorylation of the epidermal growth factor receptor on Tyr845 and Tyr1101 is associated with modulation of receptor function," Journal of Biological Chemistry, vol. 274, no. 12, pp. 8335-8343, 1999.

[10] D. R. Emlet, D. K. Moscatello, L. B. Ludlow, and A. J. Wong, "Subsets of epidermal growth factor receptors during activation and endocytosis," Journal of Biological Chemistry, vol. 272, no. 7, pp. 4079-4086, 1997.

[11] M. Rojas, S. Yao, and Y. Z. Lint, "Controlling epidermal growth factor (EGF)-stimulated Ras activation in intact cells by a cell-permeable peptide mimicking phosphorylated EGF receptor," Journal of Biological Chemistry, vol. 271, no. 44, pp. 27456-27461, 1996.

[12] R. L. Feinmesser, S. J. Wicks, C. J. Taverner, and A. Chantry, "Ca2+/calmodulin-dependent kinase II phosphorylates the epidermal growth factor receptor on multiple sites in the cytoplasmic tail and serine 744 within the kinase domain to regulate signal generation," Journal of Biological Chemistry, vol. 274, no. 23, pp. 16168-16173, 1999.

[13] S. Maudsley, W. Chadwick, L. Wang, Y. Zhou, B. Martin, and S.-S. Park, "Bioinformatic approaches to metabolic pathways analysis," Methods in Molecular Biology, vol. 756, pp. 99-130, 2011.

[14] D. J. Watts and S. H. Strogatz, "Collective dynamics of 'smallworld9 networks," Nature, vol. 393, no. 6684, pp. 440-442, 1998.

[15] H. Zhang, A. Berezov, Q. Wang et al., "ErbB receptors: from oncogenes to targeted cancer therapies," Journal of Clinical Investigation, vol. 117, no. 8, pp. 2051-2058, 2007.

[16] A. Gschwind, E. Zwick, N. Prenzel, M. Leserer, and A. Ullrich, "Cell communication networks: epidermal growth factor receptor transactivation as the paradigm for interreceptor signal transmission," Oncogene, vol. 20, no. 13, pp. 15941600, 2001.

[17] W. Wu, J. M. Samet, R. Silbajoris et al., "Heparin-binding epidermal growth factor cleavage mediates zinc-induced epidermal growth factor receptor phosphorylation," American Journal of Respiratory Cell and Molecular Biology, vol. 30, no. 4, pp. 540-547, 2004.

[18] R. P. Huang, J. X. Wu, Y. Fan, and E. D. Adamson, "UV activates growth factor receptors via reactive oxygen intermediates," Journal of Cell Biology, vol. 133, no. 1, pp. 211-220, 1996.

[19] P. J. Coffer, B. M. Burgering, M. P. Peppelenbosch, J. L. Bos, and W. Kruijer, "UV activation of receptor tyrosine kinase activity," Oncogene, vol. 11, no. 3, pp. 561-569, 1995.

[20] C. C. Miller, P. Hale, and A. P. Pentland, "Ultraviolet B injury increases prostaglandin synthesis through a tyrosine kinasedependent pathway. Evidence for UVB-induced epidermal growth factor receptor activation," Journal of Biological Chemistry, vol. 269, no. 5, pp. 3529-3533, 1994. 
[21] B. Canguilhem, A. Pradines, C. Baudouin et al., "RhoB protects human keratinocytes from UVB-induced apoptosis through epidermal growth factor receptor signaling," Journal of Biological Chemistry, vol. 280, no. 52, pp. 43257-43263, 2005.

[22] S. Pastore, F. Mascia, V. Mariani, and G. Girolomoni, "The epidermal growth factor receptor system in skin repair and inflammation," Journal of Investigative Dermatology, vol. 128, no. 6, pp. 1365-1374, 2008.

[23] T. B. El-Abaseri, S. Putta, and L. A. Hansen, "Ultraviolet irradiation induces keratinocyte proliferation and epidermal hyperplasia through the activation of the epidermal growth factor receptor," Carcinogenesis, vol. 27, no. 2, pp. 225-231, 2006.

[24] L. Voisin, S. Foisy, E. Giasson, C. Lambert, P. Moreau, and S. Meloche, "EGF receptor transactivation is obligatory for protein synthesis stimulation by G protein-coupled receptors," American Journal of Physiology, vol. 283, no. 2, pp. C446C455, 2002.

[25] H. Daub, C. Wallasch, A. Lankenau, A. Herrlich, and A. Ullrich, "Signal characteristics of G protein-transactivated EGF receptor," EMBO Journal, vol. 16, no. 23, pp. 7032-7044, 1997.

[26] H. Daub, F. U. Weiss, C. Wallasch, and A. Ullrich, "Role of transactivation of the EGF receptor in signalling by Gprotein-coupled receptors," Nature, vol. 379, no. 6565, pp. 557-560, 1996.

[27] S. Maudsley, A. M. Zamah, N. Rahman et al., "Plateletderived growth factor receptor association with $\mathrm{Na}+\mathrm{H}+$ exchanger regulatory factor potentiates receptor activity," Molecular and Cellular Biology, vol. 20, no. 22, pp. 8352-8363, 2000.

[28] W. Chadwick, A. Keselman, S. S. Park et al., "Repetitive peroxide exposure reveals pleiotropic mitogen-activated protein kinase signaling mechanisms," Journal of Signal Transduction, vol. 2011, Article ID 636951, 16 pages, 2011.

[29] K. J. Sales, S. Maudsley, and H. N. Jabbour, "Elevated prostaglandin EP2 receptor in endometrial adenocarcinoma cells promotes vascular endothelial growth factor expression via cyclic $3^{\prime}, 5^{\prime}$-adenosine monophosphate-mediated transactivation of the epidermal growth factor receptor and extracelluar signal-regulated kinase 1/2 signaling pathways," Molecular Endocrinology, vol. 18, no. 6, pp. 1533-1545, 2004.

[30] N. Prenzel, E. Zwick, H. Daub et al., "EGF receptor transactivation by G-protein-coupled receptors requires metalloproteinase cleavage of proHB-EGF," Nature, vol. 402, no. 6764, pp. 884-888, 1999.

[31] J. F. Kuemmerle and K. S. Murthy, "Coupling of the insulinlike growth factor-I receptor tyrosine kinase to Gi2 in human intestinal smooth muscle. G $\beta \gamma$-dependent mitogenactivated protein kinase activation and growth," Journal of Biological Chemistry, vol. 276, no. 10, pp. 7187-7194, 2001.

[32] F. L. Roudabush, K. L. Pierce, S. Maudsley, K. D. Khan, and L. M. Luttrell, "Transactivation of the EGF receptor mediates IGF-1-stimulated Shc phosphorylation and ERK1/2 activation in COS-7 cells," Journal of Biological Chemistry, vol. 275, no. 29, pp. 22583-22589, 2000.

[33] Q. Li, T. Hosaka, Y. Shikama et al., "Heparin-binding EGFlike growth factor (HB-EGF) mediates 5-HT-induced insulin resistance through activation of EGF receptor-ERK1/2mTOR pathway," Endocrinology, vol. 153, pp. 56-68, 2012.

[34] X. Dong, S. Park, X. Lin, K. Copps, X. Yi, and M. F. White, "Irs1 and Irs2 signaling is essential for hepatic glucose homeostasis and systemic growth," Journal of Clinical Investigation, vol. 116, no. 1, pp. 101-114, 2006.
[35] K. Yasumoto, T. Yamada, A. Kawashima et al., "The EGFR ligands amphiregulin and heparin-binding EGF-like growth factor promote peritoneal carcinomatosis in CXCR4expressing gastric cancer," Clinical Cancer Research, vol. 17, no. 11, pp. 3619-3630, 2011.

[36] C. Ferrari, C. Barbieri, and R. Caldara, "Improved oral glucose tolerance following antiserotonin treatment in patients with chemical diabetes," European Journal of Clinical Pharmacology, vol. 15, no. 6, pp. 395-399, 1979.

[37] B. Antuna-Puente, B. Feve, S. Fellahi, and J. P. Bastard, "Adipokines: the missing link between insulin resistance and obesity," Diabetes and Metabolism, vol. 34, no. 1, pp. 2-11, 2008.

[38] B. Emanuelli, P. Peraldi, C. Filloux, D. Sawka-Verhelle, D. Hilton, and E. Van Obberghen, "SOCS-3 is an insulininduced negative regulator of insulin signaling," Journal of Biological Chemistry, vol. 275, no. 21, pp. 15985-15991, 2000.

[39] R. Robertson, H. Zhou, T. Zhang, and J. S. Harmon, "Chronic oxidative stress as a mechanism for glucose toxicity of the beta cell in type 2 diabetes," Cell Biochemistry and Biophysics, vol. 48, no. 2-3, pp. 139-146, 2007.

[40] G. S. Hotamisligil, "Inflammation and endoplasmic reticulum stress in obesity and diabetes," International Journal of Obesity, vol. 32, no. 7, pp. S52-S54, 2008.

[41] Y. Huang, S. O. Kim, J. Jiang, and S. J. Frank, "Growth hormone-induced phosphorylation of epidermal growth factor (EGF) receptor in 3T3-F442A cells: modulation of EGF-induced trafficking and signaling," Journal of Biological Chemistry, vol. 278, no. 21, pp. 1890218913, 2003.

[42] M. Carty and A. G. Bowie, "Evaluating the role of Tolllike receptors in diseases of the central nervous system," Biochemical Pharmacology, vol. 81, no. 7, pp. 825-837, 2011.

[43] J. L. Koff, M. X. G. Shao, I. F. Ueki, and J. A. Nadel, "Multiple TLRs activate EGFR via a signaling cascade to produce innate immune responses in airway epithelium," American Journal of Physiology, vol. 294, no. 6, pp. L1068-L1075, 2008.

[44] S. Siddiqui and J. G. Martin, "Structural aspects of airway remodeling in asthma," Current Allergy and Asthma Reports, vol. 8, no. 6, pp. 540-547, 2008.

[45] J. L. Koff, M. X. G. Shao, S. Kim, I. F. Ueki, and J. A. Nadel, "Pseudomonas lipopolysaccharide accelerates wound repair via activation of a novel epithelial cell signaling cascade," Journal of Immunology, vol. 177, no. 12, pp. 8693-8700, 2006.

[46] M. Chokki, H. Mitsuhashi, and T. Kamimura, "Metalloprotease-dependent amphiregulin release mediates tumor necrosis factor- $\alpha$-induced IL- 8 secretion in the human airway epithelial cell line NCI-H292," Life Sciences, vol. 78, no. 26, pp. 3051-3057, 2006.

[47] M. Yamada, T. Ikeuchi, and H. Hatanaka, "The neurotrophic action and signalling of epidermal growth factor," Progress in Neurobiology, vol. 51, no. 1, pp. 19-37, 1997.

[48] J. H. Fallon, K. B. Seroogy, and S. E. Loughlin, "Epidermal growth factor immunoreactive material in the central nervous systemml: location and development," Science, vol. 224, no. 4653, pp. 1107-1109, 1984.

[49] M. H. Werner, L. B. Nanney, C. M. Stoscheck, and L. E. King, "Localization of immunoreactive epidermal growth factor receptors in human nervous system," Journal of Histochemistry and Cytochemistry, vol. 36, no. 1, pp. 81-86, 1988.

[50] H. Namba, Y. Zheng, Y. Abe, and H. Nawa, "Epidermal growth factor administered in the periphery influences excitatory synaptic inputs onto midbrain dopaminergic neurons 
in postnatal mice," Neuroscience, vol. 158, no. 4, pp. 17311741, 2009.

[51] E. Birecree, L. E. King Jr., and L. B. Nanney, "Epidermal growth factor and its receptor in the developing human nervous system," Developmental Brain Research, vol. 60, no. 2, pp. 145-154, 1991.

[52] H. I. Kornblum, R. J. Hussain, J. M. Bronstein, C. M. Gall, D. C. Lee, and K. B. Seroogy, "Prenatal ontogeny of the epidermal growth factor receptor and its ligand, transforming growth factor alpha, in the rat brain," The Journal of Comparative Neurology, vol. 380, pp. 243-261, 1997.

[53] L. Fu, A. Abu-Khalil, R. S. Morrison, D. H. Geschwind, and H. I. Kornblum, "Expression patterns of epidermal growth factor receptor and fibroblast growth factor receptor $1 \mathrm{mRNA}$ in fetal human brain," Journal of Comparative Neurology, vol. 462, no. 2, pp. 265-273, 2003.

[54] D. Caric, H. Raphael, J. Viti, A. Feathers, D. Wancio, and L. Lillien, "EGFRs mediate chemotactic migration in the developing telencephalon," Development, vol. 128, no. 21, pp. 4203-4216, 2001.

[55] A. Oyagi, S. Moriguchi, A. Nitta et al., "Heparin-binding EGF-like growth factor is required for synaptic plasticity and memory formation," Brain Research, vol. 1419, pp. 97-104, 2011.

[56] D. Sun, M. R. Bullock, N. Altememi et al., "The effect of epidermal growth factor in the injured brain after trauma in rats," Journal of Neurotrauma, vol. 27, no. 5, pp. 923-938, 2010.

[57] C. R. Chillakuri, D. Sheppard, S. M. Lea, and P. A. Handford, "Notch receptor-ligand binding and activation: insights from molecular studies," Seminars in Cell \& Developmental Biology, vol. 23, no. 4, pp. 421-428, 2012.

[58] A. Aguirre, M. E. Rubio, and V. Gallo, "Notch and EGFR pathway interaction regulates neural stem cell number and self-renewal," Nature, vol. 467, no. 7313, pp. 323-327, 2010.

[59] Y. W. Zhang, R. Wang, Q. Liu, H. Zhang, F. F. Liao, and H. Xu, "Presenilin $/ \gamma$-secretase-dependent processing of $\beta$-amyloid precursor protein regulates EGF receptor expression," Proceedings of the National Academy of Sciences of the United States of America, vol. 104, no. 25, pp. 10613-10618, 2007.

[60] T. Li, H. Wen, C. Brayton et al., "Epidermal growth factor receptor and notch pathways participate in the tumor suppressor function of $\gamma$-secretase," Journal of Biological Chemistry, vol. 282, no. 44, pp. 32264-32273, 2007.

[61] W. Chadwick, N. Mitchell, J. Caroll et al., "Amitriptylinemediated cognitive enhancement in aged $3 \times$ Tg Alzheimer's disease mice is associated with neurogenesis and neurotrophic activity," PLoS ONE, vol. 6, no. 6, Article ID e21660, 2011.

[62] K. Mishima, S. Higashiyama, Y. Nagashima et al., "Regional distribution of heparin-binding epidermal growth factor-like growth factor mRNA and protein in adult rat forebrain," Neuroscience Letters, vol. 213, no. 3, pp. 153-156, 1996.

[63] A. M. Stranahan, K. Lee, K. G. Becker et al., "Hippocampal gene expression patterns underlying the enhancement of memory by running in aged mice," Neurobiology of Aging, vol. 31, no. 11, pp. 1937-1949, 2010.

[64] A. M. Stranahan, Y. Zhou, B. Martin, and S. Maudsley, "Pharmacomimetics of exercise: novel approaches for hippocampally-targeted neuroprotective agents," Current Medicinal Chemistry, vol. 16, no. 35, pp. 4668-4678, 2009.

[65] A. M. Stranahan, Y. Zhou, B. Martin, and S. Maudsley, "Pharmacomimetics of exercise: novel approaches for hippocampally-targeted neuroprotective agents," Current Medicinal Chemistry, vol. 16, no. 35, pp. 4668-4678, 2009.

[66] B. Martin, M. Pearson, R. Brenneman et al., "Gonadal transcriptome alterations in response to dietary energy intake: sensing the reproductive environment," PLoS ONE, vol. 4, no. 1, Article ID e4146, 2009.

[67] B. Martin, M. Pearson, R. Brenneman et al., "Conserved and differential effects of dietary energy intake on the hippocampal transcriptomes of females and males," PLOS ONE, vol. 3, no. 6, Article ID e2398, 2008.

[68] L. Wang, W. Chadwick, S. S. Park et al., "Gonadotropinreleasing hormone receptor systemml: modulatory role in aging and neurodegeneration," CNS and Neurological Disorders, vol. 9, no. 5, pp. 651-660, 2010.

[69] B. Martin, M. Pearson, L. Kebejian et al., "Sex-dependent metabolic, neuroendocrine, and cognitive responses to dietary energy restriction and excess," Endocrinology, vol. 148, no. 9, pp. 4318-4333, 2007.

[70] J. Honda, S. Oomizu, Y. Kiuchi, N. Komatsu, S. Takeuchi, and S. Takahashi, "Identification of epidermal growth factor mRNA-expressing cells in the mouse anterior pituitary," Neuroendocrinology, vol. 71, no. 3, pp. 155-162, 2000.

[71] A. G. Kasselberg, D. N. Orth, M. E. Gray, and M. T. Stahlman, "Immunocytochemical localization of human epidermal growth factor/urogastrone in several human tissues," Journal of Histochemistry and Cytochemistry, vol. 33, no. 4, pp. 315322, 1985.

[72] S. G. Mueller, M. S. Kobrin, A. J. Paterson, and J. E. Kudlow, "Transforming growth factor- $\alpha$ expression in the anterior pituitary gland: regulation by epidermal growth factor and phorbol ester in dispersed cells," Molecular Endocrinology, vol. 3, no. 6, pp. 976-983, 1989.

[73] A. Mouihate and J. Lestage, "Epidermal growth factor: a potential paracrine and autocrine system within the pituitary," NeuroReport, vol. 6, no. 10, pp. 1401-1404, 1995.

[74] A. Mouihate and J. Lestage, "Estrogen increases the release of epidermal growth factor from individual pituitary cells in female rats," Journal of Endocrinology, vol. 146, no. 3, pp. 495500, 1995.

[75] G. Kontogeorgos, L. Stefaneanu, K. Kovacs, and Z. Cheng, "Localization of Epidermal Growth Factor (EGF) and Epidermal Growth Factor Receptor (EGFr) in human pituitary adenomas and nontumorous pituitaries: an immunocytochemical study," Endocrine Pathology, vol. 7, no. 1, pp. 63-70, 1996.

[76] J. Armstrong and G. V. Childs, "Changes in expression of epidermal growth factor receptors by anterior pituitary cells during the estrous cycle: cyclic expression by gonadotropes," Endocrinology, vol. 138, no. 5, pp. 1903-1908, 1997.

[77] O. Cooper, G. Vlotides, H. Fukuoka, M. I. Greene, and S. Melmed, "Expression and function of ErbB receptors and ligands in the pituitary," Endocrine-Related Cancer, vol. 18, no. 6, pp. R197-R211, 2011.

[78] S. Oomizu, J. Honda, S. Takeuchi, T. Kakeya, T. Masui, and S. Takahashi, "Transforming growth factor- $\alpha$ stimulates proliferation of mammotrophs and corticotrophs in the mouse pituitary," Journal of Endocrinology, vol. 165, no. 2, pp. 493-501, 2000.

[79] B. Borgundvaag, J. E. Kudlow, S. G. Mueller, and S. R. George, "Dopamine receptor activation inhibits estrogen-stimulated transforming growth factor- $\alpha$ gene expression and growth in anterior pituitary, but not in uterus," Endocrinology, vol. 130, no. 6, pp. 3453-3458, 1992. 
[80] G. H. Murdoch, E. Potter, and A. K. Nicolaisen, "Epidermal growth factor rapidly stimulates prolactin gene transcription," Nature, vol. 300, no. 5888, pp. 192-194, 1982.

[81] P. J. Miettinen, "Epidermal growth factor receptor in mice and men-any applications to clinical practice?" Annals of Medicine, vol. 29, no. 6, pp. 531-534, 1997.

[82] M. Sibilia, J. P. Steinbach, L. Stingl, A. Aguzzi, and E. F. Wagner, "A strain-independent postnatal neurodegeneration in mice lacking the EGF receptor," EMBO Journal, vol. 17, no. 3, pp. 719-731, 1998.

[83] P. J. Miettinen, J. E. Berger, J. Meneses et al., "Epithelial immaturity and multiorgan failure in mice lacking epidermal growth factor receptor," Nature, vol. 376, no. 6538, pp. 337341, 1995.

[84] D. W. Threadgill, A. A. Dlugosz, L. A. Hansen et al., "Targeted disruption of mouse EGF receptor: effect of genetic background on mutant phenotype," Science, vol. 269, no. 5221, pp. 230-234, 1995.

[85] M. Sibilia and E. F. Wagner, "Strain-dependent epithelial defects in mice lacking the EGF receptor," Science, vol. 269, no. 5221, pp. 234-238, 1995.

[86] H. I. Kornblum, R. Hussain, J. Wiesen et al., "Abnormal astrocyte development and neuronal death in mice lacking the epidermal growth factor receptor," Journal of Neuroscience Research, vol. 53, no. 6, pp. 697-717, 1998.

[87] R. M. Anchan, T. A. Reh, J. Angello, A. Balliet, and M. Walker, "EGF and TGF- $\alpha$ stimulate retinal neuroepithelial cell proliferation in vitro," Neuron, vol. 6, no. 6, pp. 923-936, 1991.

[88] R. S. Morrison, H. I. Kornblum, F. M. Leslie, and R. A. Bradshaw, "Trophic stimulation of cultured neurons from neonatal rat brain by epidermal growth factor," Science, vol. 238, no. 4823, pp. 72-75, 1987.

[89] R. S. Morrison, R. F. Keating, and J. R. Moskal, "Basic fibroblast growth factor and epidermal growth factor exert differential trophic effects on CNS neurons," Journal of Neuroscience Research, vol. 21, no. 1, pp. 71-79, 1988.

[90] T. Alexi and F. Hefti, "Trophic actions of transforming growth factor $\alpha$ on mesencephalic dopaminergic neurons developing in culture," Neuroscience, vol. 55, no. 4, pp. 903 918, 1993.

[91] A. Leutz and M. Schachner, "Epidermal growth factor stimulates DNA-synthesis of astrocytes in primary cerebellar cultures," Cell and Tissue Research, vol. 220, no. 2, pp. 393-404, 1981.

[92] D. L. Simpson, R. Morrison, J. De Vellis, and H. R. Herschman, "Epidermal growth factor binding and mitogenic activity on purified populations of cells from the central nervous system," Journal of Neuroscience Research, vol. 8, no. 2-3, pp. 453-462, 1982.

[93] E. Birecree, W. O. Whetsell, Stoscheck Ch., L. E. King, and L. B. Nanney, "Immunoreactive epidermal growth factor receptors in neuritic plaques from patients with Alzheimer's disease," Journal of Neuropathology and Experimental Neurology, vol. 47, no. 5, pp. 549-560, 1988.

[94] S. D. Styren, E. J. Mufson, G. C. Styren, W. H. Civin, and J. Rogers, "Epidermal growth factor receptor expression in demented and aged human brain," Brain Research, vol. 512, no. 2, pp. 347-352, 1990.

[95] S. D. Styren, S. T. DeKosky, J. Rogers, and E. J. Mufson, "Epidermal growth factor receptor expression in demented elderly: localization to vascular endothelial cells of brain, pituitary and skin," Brain Research, vol. 615, no. 2, pp. 181190, 1993.
[96] W. Chadwick, J. P. Boyle, Y. Zhou et al., "Multiple Oxygen tension environments reveal diverse patterns of transcriptional regulation in primary astrocytes," PLoS ONE, vol. 6, no. 6, Article ID e21638, 2011.

[97] M. P. Junier, Ying Jun Ma, M. E. Costa, G. Hoffman, D. F. Hill, and S. R. Ojeda, "Transforming growth factor $\alpha$ contributes to the mechanism by which hypothalamic injury induces precocious puberty," Proceedings of the National Academy of Sciences of the United States of America, vol. 88, no. 21, pp. 9743-9747, 1991.

[98] G. Zhu, M. F. Mehler, P. C. Mabie, and J. A. Kessler, "Developmental changes in neural progenitor cell lineage commitment do not depend on epidermal growth factor receptor signaling," Journal of Neuroscience Research, vol. 59, no. 3, pp. 312-320, 2000.

[99] R. C. Burrows, D. Wancio, P. Levitt, and L. Lillien, "Response diversity and the timing of progenitor cell maturation are regulated by developmental changes in EGFR expression in the cortex," Neuron, vol. 19, no. 2, pp. 251-267, 1997.

[100] J. Viti, A. Feathers, J. Phillips, and L. Lillien, "Epidermal growth factor receptors control competence to interpret leukemia inhibitory factor as an astrocyte inducer in developing cortex," Journal of Neuroscience, vol. 23, no. 8, pp. 33853393, 2003.

[101] B. Wagner, A. Natarajan, S. Grünaug, R. Kroismayr, E. F. Wagner, and M. Sibilia, "Neuronal survival depends on EGFR signaling in cortical but not midbrain astrocytes," EMBO Journal, vol. 25, no. 4, pp. 752-762, 2006.

[102] S. R. Ojeda, H. F. Urbanski, M. E. Costa, D. F. Hill, and M. Moholt-Siebert, "Involvement of transforming growth factor $\alpha$ in the release of luteinizing hormone-releasing hormone from the developing female hypothalamus," Proceedings of the National Academy of Sciences of the United States of America, vol. 87, no. 24, pp. 9698-9702, 1990.

[103] Y. J. Ma, D. F. Hill, M. P. Junier, M. E. Costa, S. E. Felder, and S. R. Ojeda, "Expression of epidermal growth factor receptor changes in the hypothalamus during the onset of female puberty," Molecular and Cellular Neurosciences, vol. 5, no. 3, pp. 246-262, 1994.

[104] B. Li, Z. Yang, J. Hou, A. McCracken, M. A. Jennings, and M. Y. J. Ma, "Compromised reproductive function in adult female mice selectively expressing mutant ErbB-1 tyrosine kinase receptors in astroglia," Molecular Endocrinology, vol. 17, no. 11, pp. 2365-2376, 2003.

[105] R. Vadigepalli, H. Hao, G. M. Miller, H. Liu, and J. S. Schwaber, "Epidermal growth factor receptor-induced circadian-time-dependent gene regulation in suprachiasmatic nucleus," NeuroReport, vol. 17, no. 13, pp. 1437-1441, 2006.

[106] D. E. Zak, H. Hao, R. Vadigepalli, G. M. Miller, B. A. Ogunnaike, and J. S. Schwaber, "Systems analysis of circadian time-dependent neuronal epidermal growth factor receptor signaling," Genome Biology, vol. 7, no. 6, article R48, 2006.

[107] A. Kramer, F. C. Yang, P. Snodgrass et al., "Regulation of daily locomotor activity and sleep by hypothalamic EGF receptor signating," Science, vol. 294, no. 5551, pp. 2511-2515, 2001.

[108] P. Snodgrass-Belt, J. L. Gilbert, and F. C. Davis, "Central administration of transforming growth factor-alpha and neuregulin-1 suppress active behaviors and cause weight loss in hamsters," Brain Research, vol. 1038, no. 2, pp. 171-182, 2005.

[109] H. Cai, W. Cong, S. Ji, S. Rothman, S. Maudsley, and B. Martin, "Metabolic dysfunction in Alzheimer's disease and 
related neurodegenerative disorders," Current Alzheimer Research, vol. 9, no. 1, pp. 5-17, 2012.

[110] B. Martin, R. Brenneman, K. G. Becker, M. Gucek, R. N. Cole, and S. Maudsley, "iTRAQ analysis of complex proteome alterations in 3xTgAD Alzheimer's mice: understanding the interface between physiology and disease," PLoS ONE, vol. 3, no. 7, Article ID e2750, 2008.

[111] B. Martin, E. Golden, A. Keselman et al., "Therapeutic perspectives for the treatment of Huntington's disease: treating the whole body," Histology and Histopathology, vol. 23, no. 2, pp. 237-250, 2008.

[112] S. Maudsley and M. P. Mattson, "Protein twists and turns in Alzheimer disease," Nature Medicine, vol. 12, no. 4, pp. 392 393, 2006.

[113] S. Maudsley, B. Martin, and L. M. Luttrell, "G proteincoupled receptor signaling complexity in neuronal tissue: implications for novel therapeutics," Current Alzheimer Research, vol. 4, no. 1, pp. 3-19, 2007.

[114] S. Maudsley, W. Chadwick, R. Brenneman, and B. Martin, "Complex and multidimensional lipid raft alterations in a murine model of Alzheimer's disease," International Journal of Alzheimer's Disease, vol. 2010, Article ID 604792, 56 pages, 2010.

[115] M. Hiramatsu, M. Kashimata, M. Murayama, N. Minami, and A. Sato, "Influence of age on epidermal growth factor receptor level in the rat brain," Experientia, vol. 44, no. 1, pp. 23-25, 1988.

[116] I. Ferrer, S. Alcántara, J. Ballabriga et al., "Transforming growth factor- $\alpha$ (TGF- $\alpha$ ) and epidermal growth factorreceptor (EGF-R) immunoreactivity in normal and pathologic brain," Progress in Neurobiology, vol. 49, no. 2, pp. 99 123, 1996.

[117] W. Chadwick, Y. Zhou, S. S. Park et al., "Minimal peroxide exposure of neuronal cells induces multifaceted adaptive responses," PLoS ONE, vol. 5, no. 12, Article ID e14352, 2010.

[118] K. A. Price, G. Filiz, A. Caragounis et al., "Activation of epidermal growth factor receptor by metal-ligand complexes decreases levels of extracellular amyloid beta peptide," International Journal of Biochemistry and Cell Biology, vol. 40, no. 9, pp. 1901-1917, 2008.

[119] D. Jiang, X. Li, R. Williams et al., "Ternary complexes of iron, amyloid- $\beta$, and nitrilotriacetic acid: binding affinities, redox properties, and relevance to iron-induced oxidative stress in Alzheimer's disease," Biochemistry, vol. 48, no. 33, pp. 79397947, 2009.

[120] K. J. Barnham, C. L. Masters, and A. I. Bush, "Neurodegenerative diseases and oxidatives stress," Nature Reviews Drug Discovery, vol. 3, no. 3, pp. 205-214, 2004.

[121] J. Villares, B. Faucheux, M. T. Herrero et al., “[125I]EGF binding in basal ganglia of patients with Parkinson's disease and progressive supranuclear palsy and in MPTP-treated monkeys," Experimental Neurology, vol. 154, no. 1, pp. 146156, 1998.

[122] G. C. O'Keeffe, P. Tyers, D. Aarsland, J. W. Dalley, R. A. Barker, and M. A. Caldwellf, "Dopamine-induced proliferation of adult neural precursor cells in the mammalian subventricular zone is mediated through EGF," Proceedings of the National Academy of Sciences of the United States of America, vol. 106, no. 21, pp. 8754-8759, 2009.

[123] S. Yoon, M. H. Choi, M. S. Chang, and J. H. Baik, "Wnt5adopamine D2 receptor interactions regulate dopamine neuron development via extracellular signal-regulated kinase (ERK) activation," Journal of Biological Chemistry, vol. 286, no. 18 , pp. 15641-15651, 2011.
[124] O. Carlson, B. Martin, K. S. Stote et al., "Impact of reduced meal frequency without caloric restriction on glucose regulation in healthy, normal-weight middle-aged men and women," Metabolism, vol. 56, no. 12, pp. 1729-1734, 2007.

[125] S. S. Park, A. M. Stranahan, W. Chadwick et al., "Cortical gene transcription response patterns to water maze training in aged mice," BMC Neuroscience, vol. 12, article 63, 2011.

[126] M. N. Harvie, M. Pegington, M. P. Mattson et al., "The effects of intermittent or continuous energy restriction on weight loss and metabolic disease risk markers: a randomized trial in young overweight women," International Journal of Obesity, vol. 35, no. 5, pp. 714-727, 2011.

[127] E. Golden, A. Emiliano, S. Maudsley et al., "Circulating brain-derived neurotrophic factor and indices of metabolic and cardiovascular health: data from the baltimore longitudinal study of aging," PLOS ONE, vol. 5, no. 4, Article ID e10099, 2010.

[128] B. Martin, E. Golden, J. M. Egan, M. P. Mattson, and S. Maudsley, "Reduced energy intake: the secret to a long and healthy life?” IBS Journal of Science, vol. 2, pp. 35-39, 2007.

[129] J. B. Johnson, W. Summer, R. G. Cutler et al., "Alternate day calorie restriction improves clinical findings and reduces markers of oxidative stress and inflammation in overweight adults with moderate asthma," Free Radical Biology and Medicine, vol. 42, pp. 665-674, 2007.

[130] B. Martin, M. P. Mattson, and S. Maudsley, "Caloric restriction and intermittent fasting: two potential diets for successful brain aging," Ageing Research Reviews, vol. 5, no. 3, pp. 332-353, 2006.

[131] R. Derynck, D. V. Goeddel, and A. Ullrich, "Synthesis of messenger RNAs for transforming growth factors $\alpha$ and $\beta$ and the epidermal growth factor receptor by human tumors," Cancer Research, vol. 47, no. 3, pp. 707-712, 1987.

[132] A. J. Wong, J. M. Ruppert, S. H. Bigner et al., "Structural alterations of the epidermal growth factor receptor gene in human gliomas," Proceedings of the National Academy of Sciences of the United States of America, vol. 89, no. 7, pp. 2965-2969, 1992.

[133] S. Menzo, M. Clementi, E. Alfani et al., "Trans-activation of epidermal growth factor receptor gene by the hepatitis B virus X-gene product," Virology, vol. 196, no. 2, pp. 878-882, 1993.

[134] Y. Yarden and M. X. Sliwkowski, "Untangling the ErbB signalling network," Nature Reviews Molecular Cell Biology, vol. 2, no. 2, pp. 127-137, 2001.

[135] I. Sadaf Farooqi and S. O'Rahilly, "Leptin: a pivotal regulator of human energy homeostasis," American Journal of Clinical Nutrition, vol. 89, no. 3, pp. 980S-984S, 2009.

[136] M. Amishima, M. Munakata, Y. Nasuhara et al., "Expression of epidermal growth factor and epidermal growth factor receptor immunoreactivity in the asthmatic human airway," American Journal of Respiratory and Critical Care Medicine, vol. 157, no. 6, pp. 1907-1912, 1998.

[137] M. Kimura, H. Inoue, K. Hirabayashi, H. Natsume, and M. Ogihara, "Glycyrrhizin and some analogues induce growth of primary cultured adult rat hepatocytes via epidermal growth factor receptors," European Journal of Pharmacology, vol. 431, no. 2, pp. 151-161, 2001.

[138] M. Kashimata, M. Hiramatsu, and N. Minami, "Sex difference and regulatory mechanism of epidermal growth factor receptor in the rat liver," Folia Pharmacologica Japonica, vol. 96, no. 4, pp. 169-183, 1990.

[139] A. Natarajan, B. Wagner, and M. Sibilia, "The EGF receptor is required for efficient liver regeneration," Proceedings of the 
National Academy of Sciences of the United States of America, vol. 104, no. 43, pp. 17081-17086, 2007.

[140] V. R. Mukku, "Regulation of epidermal growth factor receptor levels by thyroid hormone," Journal of Biological Chemistry, vol. 259, no. 10, pp. 6543-6547, 1984.

[141] M. Kashimata, M. Hiramatsu, and N. Minami, "Sex difference in epidermal growth factor receptor levels in rat liver plasma membrane," Endocrinology, vol. 122, no. 5, pp. 1707$1714,1988$.

[142] G. R. Freidenberg, H. H. Klein, and M. P. Kladde, "Regulation of epidermal growth factor receptor number and phosphorylation by fasting in rat liver," Journal of Biological Chemistry, vol. 261, no. 2, pp. 752-757, 1986.

[143] H. S. Earp and E. J. O'Keefe, "Epidermal growth factor receptor number decreases during rat liver regeneration," Journal of Clinical Investigation, vol. 67, no. 5, pp. 1580-1583, 1981.

[144] M. Okamoto, C. R. Kahn, R. Maron, and M. F. White, "Decreased autophosphorylation of EGF receptor in insulindeficient diabetic rats," American Journal of Physiology, vol. 254, no. 4, p. 17/4, 1988.

[145] A. Lev-Ran, D. L. Hwang, and G. Barseghian, "Decreased expression of liver epidermal growth factor receptors in rats with alloxan and streptozotocin diabetes," Biochemical and Biophysical Research Communications, vol. 137, no. 1, pp. 258-262, 1986.

[146] M. Kashimata, M. Hiramatsu, and N. Minami, "Effect of streptozotocin-induced diabetes on epidermal growth factor receptors in rat liver plasma membrane," Biochimica et Biophysica Acta, vol. 923, no. 3, pp. 496-500, 1987.

[147] S. Kasayama, M. Yoshimura, and T. Oka, "Decreased expression of hepatic epidermal growth factor receptor gene in diabetic mice," Journal of Molecular Endocrinology, vol. 3, no. 1, pp. 49-56, 1989.

[148] Y. Natsumi, M. Kashimata, and M. Hiramatsu, "Effect of experimental diabetes on epidermal growth factor (EGF) receptors in the rat liver," Meikai Daigaku Shigaku Zasshi, vol. 18, no. 1, pp. 21-36, 1989.

[149] L. Musallam, C. Éthier, P. S. Haddad, and M. Bilodeau, "Role of EGF receptor tyrosine kinase activity in antiapoptotic effect of EGF on mouse hepatocytes," American Journal of Physiology, vol. 280, no. 6, pp. G1360-G1369, 2001.

[150] M. Y. Lee, S. H. Park, Y. J. Lee, J. S. Heo, J. H. Lee, and H. J. Han, "EGF-induced inhibition of glucose transport is mediated by PKC and MAPK signal pathways in primary cultured chicken hepatocytes," American Journal of Physiology, vol. 291, no. 4, pp. G744-G750, 2006.

[151] T. Yamauchi, K. Ueki, K. Tobe et al., "Tyrosine phosphorylation of the EGF receptor by the kinase Jak2 is induced by growth hormone," Nature, vol. 390, no. 6655, pp. 91-96, 1997.

[152] G. A. Abou-Rjaily, J. L. Sang, D. May et al., "CEACAM1 modulates epidermal growth factor receptor-mediated cell proliferation," Journal of Clinical Investigation, vol. 114, no. 7, pp. 944-952, 2004.

[153] R. A. DeFronzo and E. Ferrannini, "Insulin resistance: a multifaceted syndrome responsible for NIDDM, obesity, hypertension, dyslipidemia, and atherosclerotic cardiovascular disease," Diabetes Care, vol. 14, no. 3, pp. 173-194, 1991.

[154] M. Harvie, L. Hooper, and A. H. Howell, "Central obesity and breast cancer risk: a systematic review," Obesity Reviews, vol. 4, no. 3, pp. 157-173, 2003.

[155] E. E. Calle, C. Rodriguez, K. Walker-Thurmond, and M. J. Thun, "Overweight, obesity, and mortality from cancer in a prospectively studied cohort of U.S. Adults," New England Journal of Medicine, vol. 348, no. 17, pp. 1625-1638, 2003.

[156] N. Vacaresse, I. Lajoie-Mazenc, N. Augé et al., "Activation of epithelial growth factor receptor pathway by unsaturated fatty acids," Circulation Research, vol. 85, no. 10, pp. 892-899, 1999.

[157] A. Soto-Guzman, N. Navarro-Tito, L. Castro-Sanchez, R. Martinez-Orozco, and E. P. Salazar, "Oleic acid promotes MMP-9 secretion and invasion in breast cancer cells," Clinical and Experimental Metastasis, vol. 27, no. 7, pp. 505-515, 2010.

[158] S. E. Baldeweg, A. Golay, A. Natali, B. Balkau, S. Del Prato, and S. W. Coppack, "Insulin resistance, lipid and fatty acid concentrations in 867 healthy Europeans," European Journal of Clinical Investigation, vol. 30, no. 1, pp. 45-52, 2000.

[159] T. Hajri, X. X. Han, A. Bonen, and N. A. Abumrad, "Defective fatty acid uptake modulates insulin responsiveness and metabolic responses to diet in CD36-null mice," Journal of Clinical Investigation, vol. 109, no. 10, pp. 1381-1389, 2002.

[160] S. Higashiyama, J. A. Abraham, J. Miller, J. C. Fiddes, and M. Klagsbrun, "A heparin-binding growth factor secreted by macrophage-like cells that is related to EGF," Science, vol. 251, no. 4996, pp. 936-939, 1991.

[161] P. J. Miettinen and K. Heikinheimo, “Transforming growth factor-alpha (TGF- $\alpha$ ) and insulin gene expression in human fetal pancreas," Development, vol. 114, no. 4, pp. 833-840, 1992.

[162] P. J. Miettinen, M. A. Huotari, T. Koivisto et al., "Impaired migration and delayed differentiation of pancreatic islet cells in mice lacking EGF-receptors," Development, vol. 127, no. 12, pp. 2617-2627, 2000.

[163] E. Hakonen, J. Ustinov, I. Mathijs et al., "Epidermal growth factor (EGF)-receptor signalling is needed for murine beta cell mass expansion in response to high-fat diet and pregnancy but not after pancreatic duct ligation," Diabetologia, vol. 54, no. 7, pp. 1735-1743, 2011.

[164] M. A. Huotari, P. J. Miettinen, J. Palgi et al., "ErbB signaling regulates lineage determination of developing pancreatic islet cells in embryonic organ culture," Endocrinology, vol. 143, no. 11, pp. 4437-4446, 2002.

[165] L. Vinter-Jensen, C. O. Juhl, P. S. Teglbjaerg, S. S. Poulsen, E. Z. Dajani, and E. Nexo, "Systemic treatment with epidermal growth factor in pigs induces ductal proliferations in the pancreas," Gastroenterology, vol. 113, no. 4, pp. 1367-1374, 1997.

[166] C. Cras-Méneur, L. Elghazi, P. Czernichow, and R. Scharfmann, "Epidermal growth factor increases undifferentiated pancreatic embryonic cells in vitro: a balance between proliferation and differentiation," Diabetes, vol. 50, no. 7, pp. 1571-1579, 2001.

[167] A. L. Means, K. C. Ray, A. B. Singh et al., "Overexpression of Heparin-binding EGF-like growth factor in mouse pancreas results in fibrosis and epithelial metaplasia," Gastroenterology, vol. 124, no. 4, pp. 1020-1036, 2003.

[168] J. Buteau, S. Foisy, E. Joly, and M. Prentki, "Glucagonlike peptide 1 induces pancreatic $\beta$-cell proliferation via transactivation of the epidermal growth factor receptor," Diabetes, vol. 52, no. 1, pp. 124-132, 2003.

[169] D. J. Drucker, “Glucagon-like peptides," Diabetes, vol. 47, no. 2, pp. 159-169, 1998.

[170] C. Widmann, E. Burki, W. Dolci, and B. Thorens, "Signal transduction by the cloned glucagon-like peptide-1 receptor: comparison with signaling by the endogenous receptors of $\beta$ 
cell lines," Molecular Pharmacology, vol. 45, no. 5, pp. 10291035, 1994.

[171] M. C. Chapter, C. M. White, A. DeRidder, W. Chadwick, B. Martin, and S. Maudsley, "Chemical modification of Class II G protein-coupled receptor ligands: frontiers in the development of peptide analogs as neuroendocrine pharmacological therapies," Pharmacology and Therapeutics, vol. 125, no. 1, pp. 39-54, 2010.

[172] J. Buteau, S. Foisy, E. Joly, and M. Prentki, "Glucagonlike peptide 1 induces pancreatic $\beta$-cell proliferation via transactivation of the epidermal growth factor receptor," Diabetes, vol. 51, pp. A375-A376, 2003.

[173] W. Chadwick, Y. Zhou, S. S. Park et al., "Minimal peroxide exposure of neuronal cells induces multifaceted adaptive responses," PloS ONE, vol. 5, no. 12, Article ID e14352, 2010.

[174] E. Roztocil, S. M. Nicholl, and M. G. Davies, "Insulininduced epidermal growth factor activation in vascular smooth muscle cells is ADAM-dependent," Surgery, vol. 144, no. 2, pp. 245-251, 2008.

[175] E. B. Leof, W. Wharton, J. J. Van Wyk, and W. J. Pledger, "Epidermal growth factor (EGF) and somatomedin C regulate G1 progression in competent BALB/c-3T3 cells," Experimental Cell Research, vol. 141, no. 1, pp. 107-115, 1982.

[176] S. Saad, V. A. Stevens, L. Wassef et al., "High glucose transactivates the EGF receptor and up-regulates serum glucocorticoid kinase in the proximal tubule," Kidney International, vol. 68, no. 3, pp. 985-997, 2005.

[177] S. Cohen and G. Carpenter, "Human epidermal growth factor: isolation and chemical and biological properties," Proceedings of the National Academy of Sciences of the United States of America, vol. 72, no. 4, pp. 1317-1321, 1975.

[178] K. J. Barnham and P. C. Amadoruge, "Alzheimer's disease and metals: a review of the involvement of cellular membrane receptors in metallosignalling," International Journal of Alzheimer's Disease, vol. 2011, Article ID 542043, 9 pages, 2011.

[179] G. R. Lewin and Y. A. Barde, "Physiology of the neurotrophins," Annual Review of Neuroscience, vol. 19, pp. 289317, 1996.

[180] B. Connor, D. Young, Q. Yan, R. L. M. Faull, B. Synek, and M. Dragunow, "Brain-derived neurotrophic factor is reduced in Alzheimer's disease," Molecular Brain Research, vol. 49, no. 12, pp. 71-81, 1997.

[181] H. S. Phillips, J. M. Hains, M. Armanini, G. R. Laramee, S. A. Johnson, and J. W. Winslow, "BDNF mRNA is decreased in the hippocampus of individuals with Alzheimer's disease," Neuron, vol. 7, no. 5, pp. 695-702, 1991.

[182] K. D. Murray, C. M. Gall, E. G. Jones, and P. J. Isackson, "Differential regulation of brain-derived neurotrophic factor and type II calcium/calmodulin-dependent protein kinase messenger RNA expression in Alzheimer's disease," Neuroscience, vol. 60, no. 1, pp. 37-48, 1994.

[183] M. Narisawa-Saito, K. Wakabayashi, S. Tsuji, H. Takahashi, and H. Nawa, "Regional specificity of alterations in NGF, BDNF and NT-3 levels in Alzheimer's disease," NeuroReport, vol. 7, no. 18, pp. 2925-2928, 1996.

[184] G. Chen, R. Kolbeck, Y. A. Barde, T. Bonhoeffer, and A. Kossel, "Relative contribution of endogenous neurotrophins in hippocampal long-term potentiation," Journal of Neuroscience, vol. 19, no. 18, pp. 7983-7990, 1999.

[185] A. H. Kossel, S. B. Cambridge, U. Wagner, and T. Bonhoeffer, "A caged Ab reveals an immediate/instructive effect of BDNF during hippocampal synaptic potentiation," Proceedings of the National Academy of Sciences of the United States of America, vol. 98, no. 25, pp. 14702-14707, 2001. 


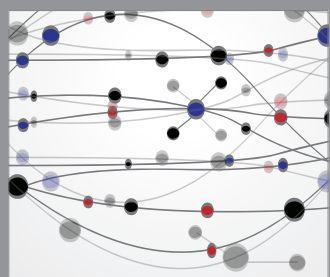

The Scientific World Journal
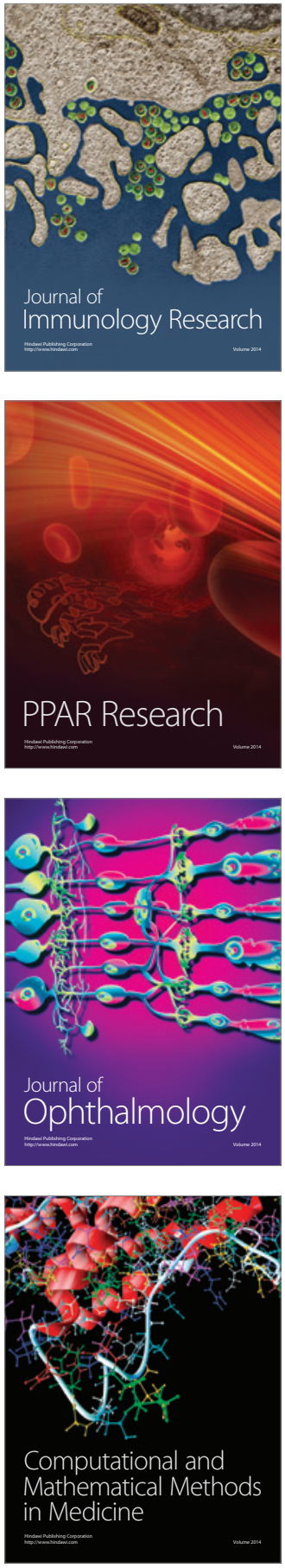

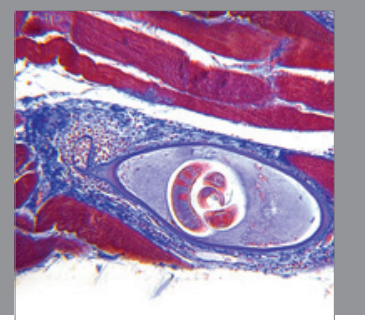

Gastroenterology

Research and Practice
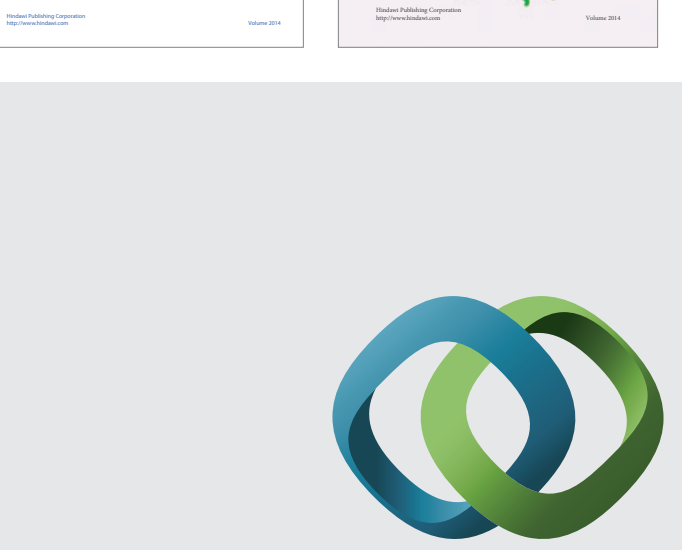

\section{Hindawi}

Submit your manuscripts at

http://www.hindawi.com
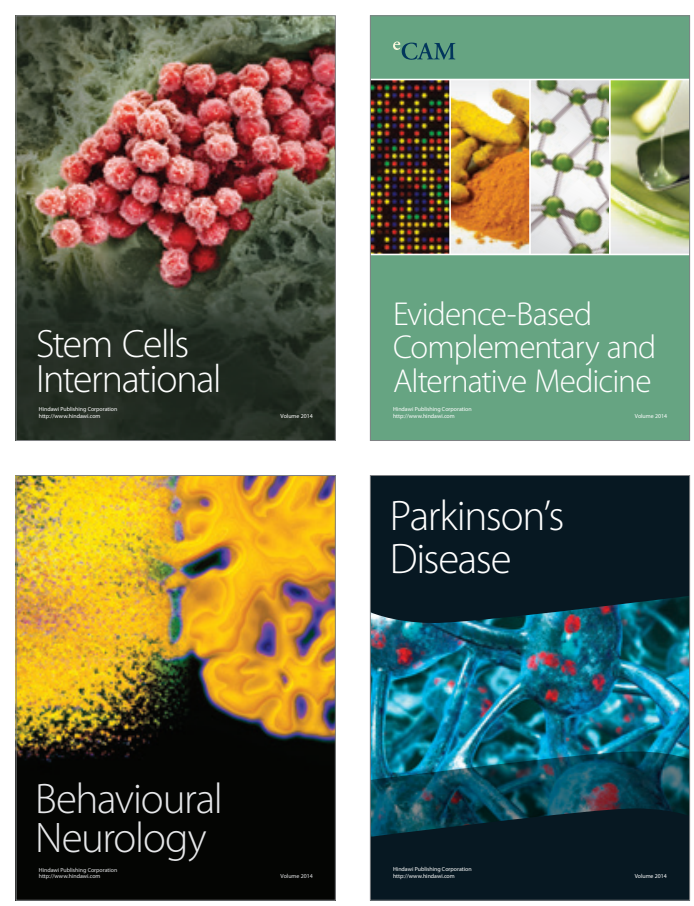

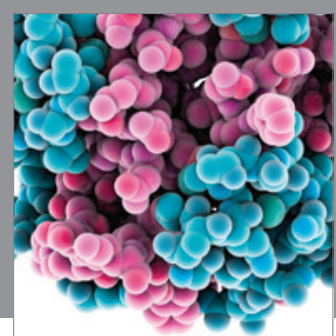

Journal of
Diabetes Research

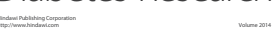

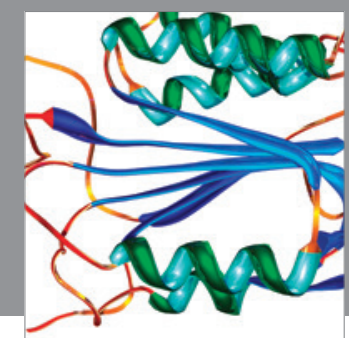

Disease Markers
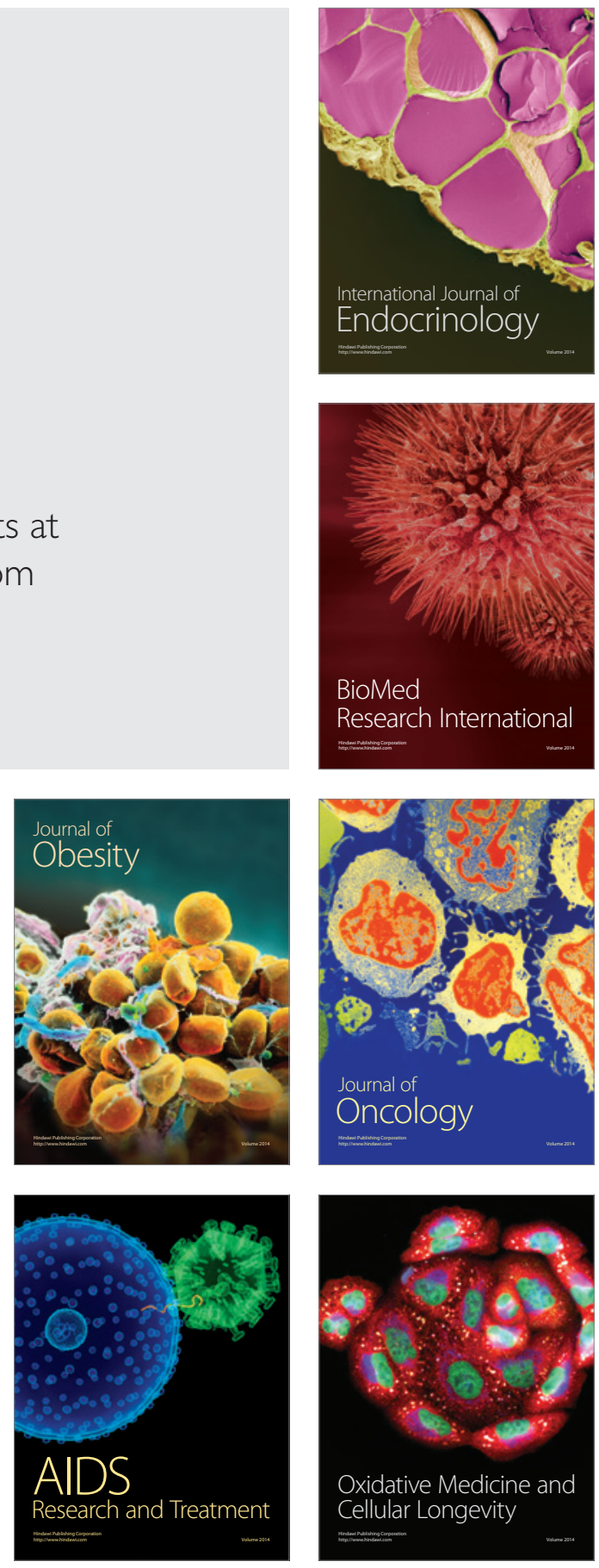